\title{
Unwanted Pregnancy and Abortion in Private Clinics
}

\author{
Siniša Franjić* \\ International University of Brcko District, Bosnia and Herzegovina
}

Submission: December 17, 2017; Published: January 03, 2019

*Corresponding author: Sinisa Franjic, International University of Brcko District, Bosnia and Herzegovina

\section{Birth Control}

The failed medical takeover underscored the obstacles to both medical approval of family planning and medical management of clinics, even as more doctors were prescribing contraception in private practice [1]. Despite Sanger's (Margaret Sanger, American birth control activist) careful cultivation of scientists and academics of all stripes, conservative medicine still viewed her as a radical and expressed unease with the sexual subtext of birth control-and even hostility toward the idea of women's sexual autonomy. Furthermore, most physicians continued to reject the movement's economic rationale for contraception and preferred to limit access to those who suffered from serious health problems.

State and federal laws reinforced this position. Physician groups also struggled with the clinic model offered by the birth control movement in the same way as they resisted the encroachment of social welfare programs that crossed over into the medical realm, such as nutritional, maternal, and infant care initiatives. These efforts often endowed laypeople with a certain degree of medical authority and sometimes competed with for-profit medical services. The medical establishment seemed especially off ended by health campaigns with laywomen in leadership positions and excessively critical of women doctors in the birth control movement.

Birth control is a common name for many different procedures whose purpose is to prevent the child's conceive, butalso to prevent the birth of an already conceived fetus [2]. The most commonly used method for this purpose is called a contraceptive method. On the other hand, the term abortion refers to a procedure that represents the physical removal of the fetus and means its death. Birth control is a controversial topic around the world.

Of great significance in terms of human rights is also the question how open the access to private healthcare services must be [3]. It is largely undisputed that also private healthcare facilities may not deny emergency treatment to anybody, but access to private services which go beyond this is commonly not possible or affordable for everybody. This is a problem particularly when at the same time there is no comprehensive public healthcare sector or where this is of a poor quality. In this case the state must ensure that a qualitatively adequate healthcare provision is accessible to everybody, either by way of respective regulation of private providers or by expanding the public healthcare sector, something which already refers to the obligations to fulfil.

\section{Abortion}

Unwanted pregnancy and contraceptive effectiveness are of interest both as indicators of the extent to which family size preferences may be achieved and also as a means of evaluating the impact of contraceptive services [4]. The use of proxy measures such as abortion and illegitimacy was seen to be problematic, but there are also limitations in a sample survey approach.

On the public level, abortion was rarely discussed [5]. (Whether this was because it was associated with sexuality and reproduction or whether it was publicly assumed to be a sin in itself is not clear.) On the private level, however, people drew a distinction between what was moral and what was proper, or at least proper for public discussion. In intimate circles or in the privacy of the medical consulting room, women may have been very frank about their abortion experiences, and abortion, in certain circles, could be accepted as a normal fact of life. But the "medicalization" of abortion and the concurrent creation of "criminal" abortions outside the pale of polite discussion acted together to do for individuals what the doctrine of medical judgment did for physicians, namely, obscure deep divisions in public attitudes about the morality (in contrast to the propriety) of abortions.

Men's rights proponents make a number of arguments to support their right to participate in abortion decisions [6]. Most focus on what seems to be a profoundly uneven and unfair distribution of power, with women holding too much and men too little. For example, they argue, whereas a man can be forced to accept the legal obligations of paternity, including the financial obligations, he cannot prevent a woman from having an abortion. On the other hand, a woman can decide to end a pregnancy by abortion, and she can also force a man to support a child she gives birth to, even if the pregnancy was unintended or unwanted by the father. Women's rights advocates point out that because pregnancy and delivery carry inherent risks to a woman's health and life, decisions about continuing or ending a pregnancy must always be a woman's decision. 
In many jurisdictions, abortion has been, or continues to be, prohibited unless legal exceptions apply [7]. A notable exception to this approach can be found in the United States, where women have a constitutional right to privacy that encompasses the right to terminate a pregnancy (at least until viability, when the state's interest becomes compelling). However, in many jurisdictions where no such right is recognized, lawful abortion has historically been tethered to assessments of the danger posed by the pregnancy to the life or health of the woman. Although this "maternal health" exception has been interpreted as broad enough to encompass abortion for serious fetal abnormalities, some jurisdictions have created a distinct exception to permit abortion to avoid the risk of "serious handicap." The impetus for such an exception has resulted from the tremendous recent advances in prenatal diagnosis. Although such advances have enabled these abortions to take place earlier in pregnancy, they have also enabled doctors to detect serious conditions only diagnosable later in pregnancy. Because these abortions sometimes occur after viability, arguments about "serious handicap" as a regulatory concept tend to converge upon arguments about the status of the fetus as birth approaches.

\section{Abortion in Private Practice}

In the 20th century, abortion was very much taboo, and a woman could obtain a legal abortion only to preserve her life, or, in some States, to preserve her health [8]. The pro-abortion movement then started to gather momentum in the early 1960s, when many feminist activists began to press for economic issues, and this developed into a campaign for the recognition of certain inalienable social rights of women. Gradually, the right of abortion began to be considered as one of these rights. It needs to be mentioned at this point that, apart from the moral and political and even gender debates, the reality was that affluent women were able to secure 'safe' abortions which could be performed by a discreet private physician in private practice. In addition, they could also travel to those European countries where abortion was freely available.

While many of the abortion providers have found that women do not attend support groups after their abortions, usually because pre-abortion counseling properly identifies high-risk women and recommends therapy with private therapists, we have found that most private therapists have had little training or knowledge about what are the usual issues raised by women who seek abortion [9]. Experiences say that most of the emotional difficulties experienced by women post-abortion can be identified before the pregnancy is terminated. Some of the emotional problems can be directly attributed to the politics of abortion with women feeling as if they are caught in a war that is much larger than their own choice to terminate a pregnancy. However, given the rise of these new abortion-recovery centers, most of which provide biased, faith-based counseling, we believe that it is important for women to have options for counseling that is based on psychological theories and science.
The inconsistencies in physicians' rationales for agreeing or refusing to perform abortions underscored the unusual nature of this medical responsibility [10]. Avoidance of abortion, particularly by those best trained to perform it, appeared to violate professional standards which demanded that the best possible care be given, but it affirmed an even deeper expectation about the privileges aff orded physicians in private practice. Of course, the physician's privilege not to perform an abortion placed a constraint on the right of a woman to have one performed. In the minds of many doctors, the abortion clinic had become the logical response to this constraint. It represented the institutionalization of abortion that the private practice of medicine, however unintentionally, resisted. The organization of resistance to abortion had other features, not least of which was the physician's acknowledgment of what was aborted.

The confrontations that shape the politics of birth control at the national level dissolve in the face of the day-to-day medical practices of doctors, who remain the sole legal providers of abortion and other forms of birth control. Obstetrician/gynecologists assume the primary surgical and medical responsibilities for such procedures as sexual sterilization and abortion and for the prescription of diaphragms, IUDs (intrauterine devices), and oral contraceptives.

Whether for reasons of safety, efficiency, or convenience, the modern development of birth control has increased the participation of professionals, including physicians, research scientists, and social workers, in the monitoring and controlling of birth.

\section{References}

1. Engelman PC (2011) A History of the Birth Control Movement in America. ABC-CLIO 1: 155-156.

2. Siniša F (2018) Birth Control. J Gynecol Women's Health 12(1): 1-5.

3. Krennerich M (2017) The Human Right to Health: Fundamentals of a Complex Right. In: Klotz S, Bielefeldt H, Schmidhuber M, Frewer A (eds), Healthcare as a Human Rights Issue-Normative Profile, Conflicts and Implementation. Transcript Verlag, Bielefeld, Germany, pp. 38.

4. Selman PF (1988) Family Planning, Chapman and Hall, New York, USA, pp. 97.

5. Luker K (1984) Abortion and the Politics of Motherhood. University of California Press, Berkeley, USA, pp. 54.

6. Solinger R (2013) Reproductive Politics-What Everyone Needs To Know. Oxford University Press, Oxford, UK, pp. 143.

7. Isabel K, Kristin S (2012) Perfecting Pregnancy-Law, Disability, and the Future of Reproduction. Cambridge University Press, Cambridge, UK, pp. 106-107.

8. de Cruz P (2001) Comparative Healthcare Law. Cavendish Publishing Limited, London, UK, pp. 420.

9. Needle RB, Walker LEA (2008) Abortion Counseling-A Clinician's Guide to Psychology, Legislation, Politics, and Competency. Springer Publishing Company, LLC, New York, USA, pp. 34.

10. Imber JB (2017) Abortion and the Private Practice of Medicine. Routledge, Taylor \& Francis Group, Abingdon, USA, pp. 37-73. 
(C) This work is licensed under Creative

BY DOI: 10.19080/JGWH.2019.13.555870
Your next submission with Juniper Publishers will reach you the below assets

- Quality Editorial service

- Swift Peer Review

- Reprints availability

- E-prints Service

- Manuscript Podcast for convenient understanding

- Global attainment for your research

- Manuscript accessibility in different formats ( Pdf, E-pub, Full Text, Audio)

- Unceasing customer service

Track the below URL for one-step submission https://juniperpublishers.com/online-submission.php 